\title{
CELOS bulletins
}

10. 12

REARING OF DIATRAEA SACCHARALIS ON DIETS IN SURINAM

J. B. M. VAN DINTHER \& P. A. GOOSSENS

Reprinted from:

Entomologica Experimentalis et Applicata, vol. 13 (1970), pp. 320-326 


\title{
REARING OF DIATRAEA SACCHARALIS ON DIETS IN SURINAM
}

\author{
BY

\section{J. B. M. VAN DINTHER and P. A. GOOSSENS}

Laboratory of Entomology, Agricultural University, Wageningen, the Netherlands, and Centre of Agricuitural Research, Paramaribo, Surinam, respectively

Mass rearing of the borer Diatraea saccharalis (F.) was attempted on a limited scale. Out of nine non-aseptic artificial diets tested fair results were obtained with the medium containing kidney bean meal $(35 \mathrm{~g})$, corn plant powder $(10 \mathrm{~g})$, carrot powder $(5 \mathrm{~g})$, brewer's yeast $(10 \mathrm{~g})$, casein $(1 \mathrm{~g})$, ascorbic acid $(0.5 \mathrm{~g})$, agar $(3 \mathrm{~g})$, water $(210 \mathrm{~g})$ and the antimicrobial agents methylparahydroxybenzoate $(1 \mathrm{~g})$, streptomycine sulphate $(0.1 \mathrm{~g})$, penicillin $(0.2 \mathrm{~g})$ and sorbic acid $(0.2 \mathrm{~g})$.

The borer was also reared satisfactorily on cut corn stalks.

Diatraea saccharalis is one of the most important insect pests attacking sugarcane and rice in Surinam. Control by insecticides has not proved economical or feasible because the larvae live predominantly inside the plant stalks and rainfall limits or eliminates the residual effect of the insecticides (Van Dinther, 1960). As a result of this and also in view of the general objections against the application of chemicals, interest is now centred on the possibilities of biological control.

Good results have been obtained with the introduction of parasites of this borer in a number of areas of the Caribbean since the pioneer work of Myers (1934, 1935) and Box (1939 a, b). For example, on the 8000 hectare sugarcane estate "El Palmar" in the Aragua Valley, Venezuela, after the liberation of the "Amazon fly", Metagonistylum minense Tns., the mean stalk infestation by $D$. saccharalis, $D$. rosa Heinr. and D. busckella Dyar \& Heinr. gradually decreased from $16 \%$ in 1947-1950 to $2 \%$ in 1968. At this estate the fly is mass-reared and about 60,000 are released annually during May-November (Dr. José Morejon, head of the breeding and release work, pers. comm.).

By contrast, in several other countries parasite establishment was not successful. For a general review of the biological control status of moth borers reference can be made to Jepson (1954), Simmonds \& Bennett (1967) and Bennett (1969).

Envisaging the eventual introduction into Surinam of exotic parasites, preliminary research on an economically practicable mass-rearing method of the borer was started in 1968 and attention was especially directed to devising artificial diets.

Different artificial diets for lepidopterous larvae have developed in the U.S.A. 
and Puerto Rico (Adkisson, Vanderzant, Bull \& Allison, 1960; Pan \& Long, 1961; Wongsiri \& Randolph, 1962; Shorey \& Hale, 1965; Walker, Alemany, Quintana, Padovani \& Hagen, 1966; Bowling, 1967; Hensley \& Hammond, 1968).

In Surinam we tested a number of media, based on the simple recipe of Shorey \& Hale. Some new compositions and ingredients were examined. The possibility of mass rearing $D$. saccharalis on more natural food, viz. on cut rice and corn stalks, was also studied.

\section{DIETS AND PREPARATION}

Details of the components of the diets, listed in Table I, are as follows: Initially dried kidney beans (Phaseolus sp.), were soaked in water overnight, then boiled

TABLE I

$$
\text { Arrificial diets used for rearing D. saccharalis }
$$

Diet No.

$5 \quad 6$

Ingredients $(\mathrm{g})$ :

kidney beans

corn plant powder

12

4

4

50

15

carrot powder

$\begin{array}{rrrr}70 & 60 & 30 & 35 \\ 20 & 30 & 15 & 10 \\ 10 & 10 & 5 & 5\end{array}$

rice plant powder

rice polishing

brewer's yeast

casein

$\begin{array}{rrrr}15 & 15 & 7.5 & 10 \\ & 1 & 4 & 10\end{array}$

(n)

$\begin{array}{ll}30 & 20 \\ 15 & \end{array}$

5

1010

$30 \quad 20$

cane-sugar

ascorbic acid

choline chloride

agar

methylparahyưroxybenzoate

streptomycinesulphate

penicillin

sorbic acid

formaldehyde

$\mathrm{HCl}$ (1 N)

copper sulphate

Dimanin

water

$\begin{array}{llll} & & 4 & 1 \\ 1.5 & 1.5 & 1 & 0.5 \\ & & 0.2 & \\ 6 & 6 & 3 & 3 \\ 1 & 1 & 1 & 1 \\ 0.5 & 0.5 & 0.5 & 0.1 \\ & & 0.3 & 0.2 \\ & & 0.2 & 0.2 \\ & & 0.3 & \end{array}$

7.5

225

0.75

$0.75 \quad 0.5$

0.5

0.5

$3 \quad 0.2$

3.53

$\begin{array}{llllll}0.5 & 0.5 & 0.5 & 0.5 & 0.5\end{array}$

0.1

0.1

0.1

0.2

$\begin{array}{ll}0.25 & 0.3 \\ 0.5 & \end{array}$

$0.2 \quad 0.2$

0.2

0.3

and ground into pulp with a handmincer. Later the beans were applied in the form of a fine powder, made by the Department of Food Technology, Agricultural Experiment Sta:ion, Paramaribo, who also provided corn-, rice- and carrot-powder. The orginal plant materials - viz. stalks and leaves of corn- and rice-plants that had not yet reached the generative stage and imported deep-frozen roots of Dancus carota - were slowly dried at $45^{\circ} \mathrm{C}$ before grinding to preserve the vitamins and aromatics in them.

Brewer's yeast, casein, (cane) sugar, ascorbic acid, choline chloride and agar powder are among the ingredients already included in the media mentioned earlier. To prevent contamination two or more of the following antibiotics ("inhibitors") 
generally applied in artificial diets, were used: methylparahydroxybenzoate (nipagin), streptomycin, sorbic acid and formaldehyde. Penicillin, copper sulphate, Dimanin (trade-mark for a mixture of metal salts with fungicidal and bactericidal action) and hydrochloric acid $(1 \mathrm{~N})$ were also tested.

Diet 1 was prepared as follows: brewer's yeast, ascorbic acid, nipagin and streptomycin in $250 \mathrm{cc}$ of water were blended in a beaker for $15 \mathrm{sec}$ with an electric mixer. The agar, dissolved in a remaining $125 \mathrm{cc}$ of water at $40^{\circ}$, was poured over this mixture and the freshly boiled and ground beans, the corn meal and the carrot powder were added. All ingredients together were stirred for $30 \mathrm{sec}$. The medium was then poured into a plastic squeeze bottle and dispensed into rearing cups and vials. These containers were covered with paper and left open for one day to let the excess moisture evaporate. In this medium, sorbic acid and formaldehyde were omitted but streptomycin was added as a precaution to prevent rotting. The diet was enriched with corn meal and carrot powder as recommended by Walker et al., (1966).

In composing diet 2 special attention was paid to the keeping qualities. Copper sulphate, Dimanin and hydrochloric acid were added as extra bacterial and fungal inhibitors. The agar was dissolved in water at $90^{\circ}$, and brewer's yeast, corn meal and carrot powder added while stirring. At $70^{\circ}$ the remaining constituents followed and the medium was mixed for $2 \mathrm{~min}$. The cups and vials were briefly submerged in alcohol before use. After the hot medium was poured into these containers they were covered overnight with paper disinfected in alcohol.

Diet 3 comprised the ingredients used by Shorey \& Hale (1965) and also some of the components of the wheat germ medium of Adkisson et al., (1960). Hydrochloric acid, copper sulphate and Dimanin were abandoned; streptomycin and penicillin supplemented the other antimicrobial agents.

In the diets tested subsequently bean meal was used. The handmixer was replaced by a blender with a 11 beaker. The dry ingredients, except the agar, were mixed with about half of the available volume of water for $30 \mathrm{sec}$. The agar was dissolved in the remaining water at $90^{\circ}$. When cooled to $70^{\circ}$ it was added to the mixture which was blended for another $1-2 \mathrm{~min}$.

\section{REARING PROCEDURE}

The breeding work was carried out in a screened laboratory room where the mean temperature fluctuated from $24^{\circ}-28^{\circ}$ and the relative humidity ranged from about $65-90 \%$. Daylength was approximately 12 hours and no extra light was supplied.

D. saccharalis pupae, collected from rice fields at Paramaribo, formed the initial material. They were placed on a layer of moistened cotton in an open petridish and kept in a cardboard cylinder (height $30 \mathrm{~cm}$, diameter $23 \mathrm{~cm}$ ) the inner wall of which was lined with ordinary writing-paper. The open top was covered by the same type of paper whereas a $29 \mathrm{~cm}$ high and zigzag folded sheet of paper was put inside. A small wad of cotton soaked in a sugar solution was also supplied. 
Moths mated soon after emergence and egg-clusters were readily deposited on the writing-paper. Before hatching the egg-groups were cut out from the paper sheets. When not directly needed, eggs were kept in a refrigerator $\left(6^{\circ}\right)$. If freshly deposited they can be preserved in a good condition for a few days only; eggs in the "blackhead stage" can be stored up to 10 days. Pupae were kept in a similar way.

Newly hatched larvae were transferred by means of a fine brush (no. 00) to cotton wool plugged glass vials (length $10 \mathrm{~cm}$, diameter $2.5 \mathrm{~cm}$ ) containing a medium. The brush was regularly dipped into a $0.1 \%$ solution of the antisepticum "Dettol" (chloroxylenol). Initially $25 \mathrm{cc}$ plastic cups with lid were used. To assure a sufficient air supply a $2 \mathrm{~cm}$ wide hole was punched in the lid and stoppered with cotton wool. However, the use of these cups was soon abandoned because larvae may gnaw an opening in the wall.

In the experiments with stalks of rice and corn $20 \mathrm{~cm}$ long sections, cut from plants that had not reached the flowering stage, were kept in 21 glass jars. The $8 \mathrm{~cm}$ wide jar mouth was closed by a pierced wooden stopper, covered with a fine mesh gauze. One or two egg-masses were deposited on this plant material.

To ascertain the fecundity of individual females, couples of freshly emerged moths were kept in paper cups (height $20 \mathrm{~cm}$, diameter $10 \mathrm{~cm}$ ) where eggs were laid and counted.

\section{RESULTS AND DISCUSSION}

The biological data obtained have been recorded in Table II. Some diets, successfully applied elsewhere, failed to yield good results under our conditions. First-instar larvae were mobile during the first days after introduction. In the cups they finally settled in the narrow space along the wall, caused by the shrinking of the medium.

The kecping qualities of diet 1 proved to be poor. One week after larval introduction this medium had changed from light brown to a darker brown and a putrid smell was emitted. Containers revealing a slight infection only were kept for further observation. Notwithstanding the fact that the contamination soon intensified $36 \%$ of the larvae reached the pupal stage. The period necessary for the total larval development was strikingly short.

The extra inhibitors used in diet 2 prevented any decomposition but larval development was so much retarded that only a limited number of first-instar larvae had moulted after 9 days. After 6 weeks the observations were concluded when only a few larvae had attained the fourth stage.

The results obtained with diet 3 were much improved after leaving out some of the inhibitors, including Dimanin, but still about half the larvae died.

Good results were produced by medium 4, viz. a rather low larval mortality, a reasonable developmental duration, normal pupal weights and a fair production of viable eggs. Four consecutive generations of $D$. saccharalis had been reared successfully on this diet when the experiment was topped. 




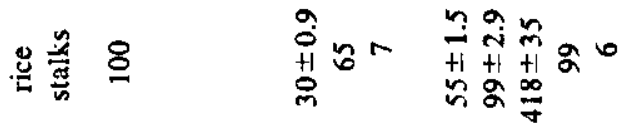

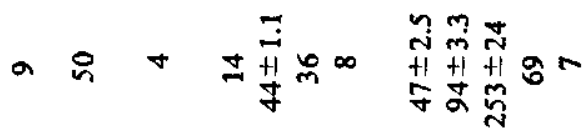

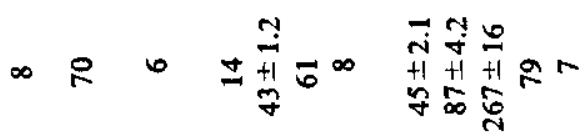



$$
\begin{aligned}
& \text { • } \\
& \text { n유 윰 }
\end{aligned}
$$

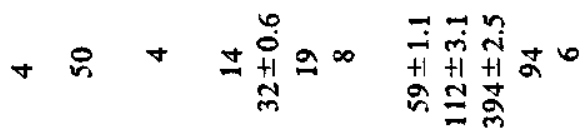

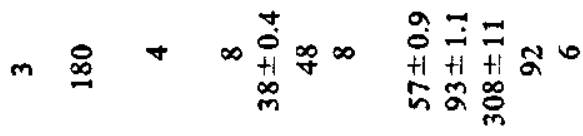

$$
\begin{aligned}
& \text { N }
\end{aligned}
$$

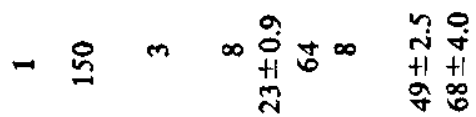

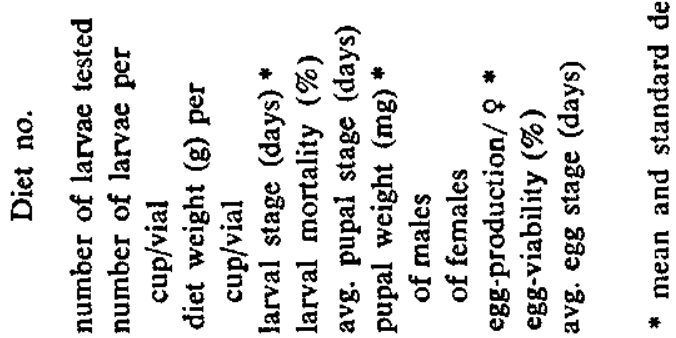


The effect on borer growth by diet 5, a copy of Bowling's (1967) recipe with only the "pinto beans" replaced by kidney beans, was disappointing. Larval development was extremely slow and mortality high among the first three instars. When the observations were terminated after 9 weeks only $25 \%$ of the larvae were still alive. This result was probably due to the pasty texture of the medium.

The outcome of diet 6, mainly composed of constituents applied by Walker et al., proved to be moderate.

Diet 7 showed some resemblance to the medium of Pan \& Long (1961). Instead of autoclaving to sterilize the medium extra fungicides were used. Again the speed of larval growth was slow and mortality high. The food consistency appeared to be too compact and limited the boring activities of the larvae.

The last two experiments conducted with artificial diets demonstrated that riceplant powder and rice polishings may replace to some extent corn meal and beans or corn meal and carrot-powder. However, the tardy growth and the high larval mortality render these diets impracticable. Thus medium 4 was the most promising diet offered.

Mass-breeding on cut rice stalks was unsatisfactory because they needed replacing every 4 to 5 days. The use of corn stalks was less laborious as they had to be renewed only once every 14 days. Since corn can be grown throughout the year and reasonable rearing results were obtained (see Table II) the breeding of $D$. saccharalis on corn needs further evaluation before a final choice of artificial diet is made.

RÉSUMÉ

\title{
ELEVAGE DE DIATRAEA SACCHARALIS SUR MILIEUX ARTIFICIELS
}

\author{
EN SURINAM
}

Lélevage de Diatraea sacharalis sur une huitaine de régimes artificiels a été étudié sous des conditions non-aseptiques. Des résultats favorables sont obtenus avec un milieu composé de: haricots rouges pulvérisées $(35 \mathrm{~g})$, tiges et feuilles de maïs réduites en poudre $(10 \mathrm{~g})$, farine de carottes $(5 \mathrm{~g})$, levure $(10 \mathrm{~g})$, caséine $(1 \mathrm{~g})$, acide ascorbique $(0,5 \mathrm{~g})$, agar $(3 \mathrm{~g})$, eau $(210 \mathrm{~g})$ et les antibiotiques: methylparahydroxybenzoate $(1 \mathrm{~g})$, streptomycine sulfate $(0.1 \mathrm{~g})$, pénicilline $(0.2 \mathrm{~g})$ et acide sorbique $(0.2 \mathrm{~g})$.

Lélevage en bocaux contenant des fragments de tiges de maïs a également donné de bons résultats.

\section{REFERENCES}

Adkisson, P. L., Vanderzant, E. S., Bull, D. L. \& Allison, W. E. (1960). A wheat germ medium for rearing the Pink Bollworm. J. econ. Ent. 53: 759-762.

BenvetT, F. D. (1969). Tachinid flies as biological control agents for sugar cane moth borers in J. R. Williams, J. R. Metcalfe et al. (Ed.): Pests of Sugar Cane: 117-148.

Bowling, C. C. (1967). Rearing of two lepidopterous pests of rice on a common artificial diet. Ann. Ent. Soc. Amer. 60: 1215-1216. 
Box, H. E. (1939a). Biological control of Diatraea saccharalis F, in St. Lucia, B.W.I. Proc. int. Soc. Sug. Cane Technol. 6 : 213-240.

(1939b). Some aspects of the campaign against the moth-borer (Diatraea saccharalis F.) in Antigua and St. Kitts, 1931-38. Proc. int. Soc. Sug. Cane Technol. 6: 495-513.

Dinther, J. B. M. van (1960). Bestrijding van rijstboorders in Suriname (Summary: Control of rice stalk borers in Surinam). Med. Landbouwhogeschool Gent $25: 1531-1541$.

HensLeY, S. D. \& HAMmond, A. B. (1968). Laboratory techniques for rearing the sugarcane moth-borer on an artificial diet. J. econ. Ent. $61: 1742-1743$.

JEPSON, W. F. (1954). A critical review of the world literature on the lepidopterous stalk borers of tropical graminaceous crops. Commonwealth Institute of Entomology, London: 94-103.

MYERs, J. G. (1934). The discovery and introduction of the Amazon fly. A new parasite for cane-borers (Diatraea). Trop. Agric., Trinidad 11: 191-195.

- (1935). Second report on an investigation into the biological control of West Indian insect pests. Bull. ent. Res. 26 : 181-252.

PaN, Y.S. \& LoNG, W. H. (1961). Diets for rearing the sugarcane borer. J. econ. Ent. 54 : $257-261$.

SHoReY, H. H. \& HaLE, R. L. (1965). Mass rearing of the larvae of nine noctuid species on a simp.e artificial medium. J. econ. Ent. 58 : $522-524$.

Simmonds, F. J. \& BenNetT, F.D. (1967). Recent investigations on the biological control of sugar-cane pests in the West-Indies. Proc. Brit. W. Ind. Sug. Technol. 1 : 301-303.

Walker, D. W., Alemany, A., Quinjana, V., Padovani, F. \& Hagen, K. S. (1966). Improved xenic diets for rearing the Sugarcane Borer in Puerto Rico. J. econ. Ent. 59: $1-4$.

WongsiRI, L. \& RANDolPh, N. M. (1962). A comparison of the biology of the Sugarcane Borer on artificial and natural diets. J. econ. Ent. $55: 472-473$. 